OPEN ACCESS

Edited by:

Gianvincenzo Zuccotti,

University of Milan, Italy

Reviewed by:

Carla Mastrorilli,

University of Parma, Italy

Rashmi Ranjan Das,

All India Institute of Medical

Sciences, India

*Correspondence:

Roberto Berni Canani berni@unina.it

†These authors have contributed equally to this work

Specialty section: This article was submitted to

Pediatric Immunology,

a section of the journal

Frontiers in Pediatrics

Received: 13 May 2020

Accepted: 23 June 2020

Published: 11 August 2020

Citation:

Carucci L, Nocerino R, Paparo L, Di Scala C and Berni Canani R (2020) Dietary Prevention of Atopic March in

Pediatric Subjects With Cow's Milk

Allergy. Front. Pediatr. 8:440.

doi: 10.3389/fped.2020.00440

\section{Dietary Prevention of Atopic March in Pediatric Subjects With Cow's Milk Allergy}

\author{
Laura Carucci $^{1,2 \dagger}$, Rita Nocerino ${ }^{1,2 \dagger}$, Lorella Paparo ${ }^{1,2}$, Carmen Di Scala ${ }^{1,2}$ and \\ Roberto Berni Canani 1,2,3,4*
}

${ }^{1}$ Department of Translational Medical Science, University of Naples Federico II, Naples, Italy, ${ }^{2}$ ImmunoNutritionLab at the CEINGE Advanced Biotechnologies Research Center, University of Naples Federico II, Naples, Italy, ${ }^{3}$ European Laboratory for the Investigation of Food-Induced Diseases, University of Naples Federico II, Naples, Italy, ${ }^{4}$ Task Force for Microbiome Studies, University of Naples Federico II, Naples, Italy

Cow's milk allergy (CMA) is one of the most prevalent food allergies and the most expensive allergic diseases in the pediatric age. There is no cure for CMA, and actual disease management is based on strict avoidance of cow milk protein-containing foods, access to rescue medication, and use of substitutive formulas. Early-life CMA could be one of the first steps of the "allergic march" (AM), leading to the occurrence of other atopic manifestations later in the life, including asthma and oculorhinitis, with subsequent further increase of costs for health care systems and families of affected children. In the last years, diet is emerged as a relevant strategy to prevent allergic diseases through, at least in part, epigenetic modulation of immune system. We provide an overview of studies that investigate the potential role of different dietary strategies in preventing the AM in pediatric patients with CMA.

Keywords: allergic march, food allergy, breast milk, infant formula, gut microbiota, epigenetics

\section{INTRODUCTION}

Affecting up to 3\% of children worldwide, cow's milk allergy (CMA) is one of the earliest and most prevalent food allergies (FA) in the pediatric age. It is also responsible for the vast majority of food-induced anaphylaxis cases in the Italian pediatric population, with significant costs for the healthcare system and families, and it emerged as one of the most expensive allergic diseases (1-8).

Although most subjects with CMA naturally outgrow it over time, studies evidence a wide range of ages and rates of resolution with an increased risk of persistence in recent decades, mainly due to negative gene-environment interaction leading to the breakdown of immune tolerance mechanisms (9-12). In addition, evidence suggests that early-life CMA could be one of the first steps of the "allergic march" (AM), leading to the occurrence of other allergic disorders during childhood. Indeed, the occurrence of allergic sensitization in these children increases the risk of later developing asthma and allergic oculorhinitis (AR), in particular when sensitization occurs along with atopic dermatitis (AD) (13-15). Figure 1 depicts the natural history of AM in CMA children. According to data from several clinical 
studies, up to $45 \%$ of CMA children develop other atopic manifestations later in the life, also after the immune tolerance acquisition to cow milk proteins $(3,5,16-18)$. The development of AM is driven by genetic predisposition, but environmental factors may play a key role in its clinical expression. Indeed, as shown by longitudinal studies, only a minority of children follow the classic pathway of AM (starting from $\mathrm{AD}$ and followed by sequential development of FA, asthma, and AR) $(19,20)$. Earlier recognition of at-risk infants, regardless of CMA temporal appearance, allows fielding effective strategies to limit the occurrence of other atopic manifestations later in the life.

There is no cure for CMA, and actual disease management is based on strict avoidance of cow's milk protein-containing foods, access to rescue medication, and use of substitutive formulas (21-25).

Due to the increasing prevalence, persistence, and risk for developing other atopic manifestations in children with CMA, preventive strategies are highly advocated. In the last years, diet is emerging as a relevant strategy to prevent allergic diseases through the active modulation of the immune system (26). This review is focused on the potential role of different dietary strategies in preventing the AM in pediatric patients with CMA.

\section{THE POTENTIAL OF BREASTFEEDING}

Breastfeeding is the best dietary strategy for newborn infants due to its optimal nutritional properties and several bioactive compounds that influence health status. Studies suggest a protective role on the onset of $\mathrm{FA}$, asthma, and $\mathrm{AD}$, both in low- and high-risk infants breastfed for at least 3-4 months (27-33). A WHO report suggests that allergic diseases are lower in exclusively breastfed compared to non-breastfed infants (34). A reduction of about $4 \%$ in FA risk for every additional month of exclusive breastfeeding has also been estimated (35). Unfortunately, most available data on breastfeeding and allergic diseases are based on observational, retrospective, underpowered studies, and present several confounding factors, such as the inclusion of partially breastfed infants $(36,37)$. Another limiting aspect is that the protective mechanisms against FA and other atopic manifestations are still not completely characterized. Breast milk contains several potential protective factors against allergy. Some compounds could be able to exert an indirect effect on immune system through a modulation of infant gut microbioma $(\mathrm{GM})$, whereas other components could exert a direct modulatory effect on the infant immune system toward a protection against allergic diseases $(38,39)$ (Table $\mathbf{1})$.

The GM is emerging as a pivotal regulator of immune tolerance development (6). Breastfeeding shapes infant GM, both by direct transition of the human milk bacteria (HMBs), and indirectly through milk compounds such as human milk oligosaccharides (HMOs), secretory IgA, and antimicrobial factors, which could impact bacterial growth and metabolism (40). Studies have suggested that breast milk owns unique microbiome, including beneficial commensal and potentially

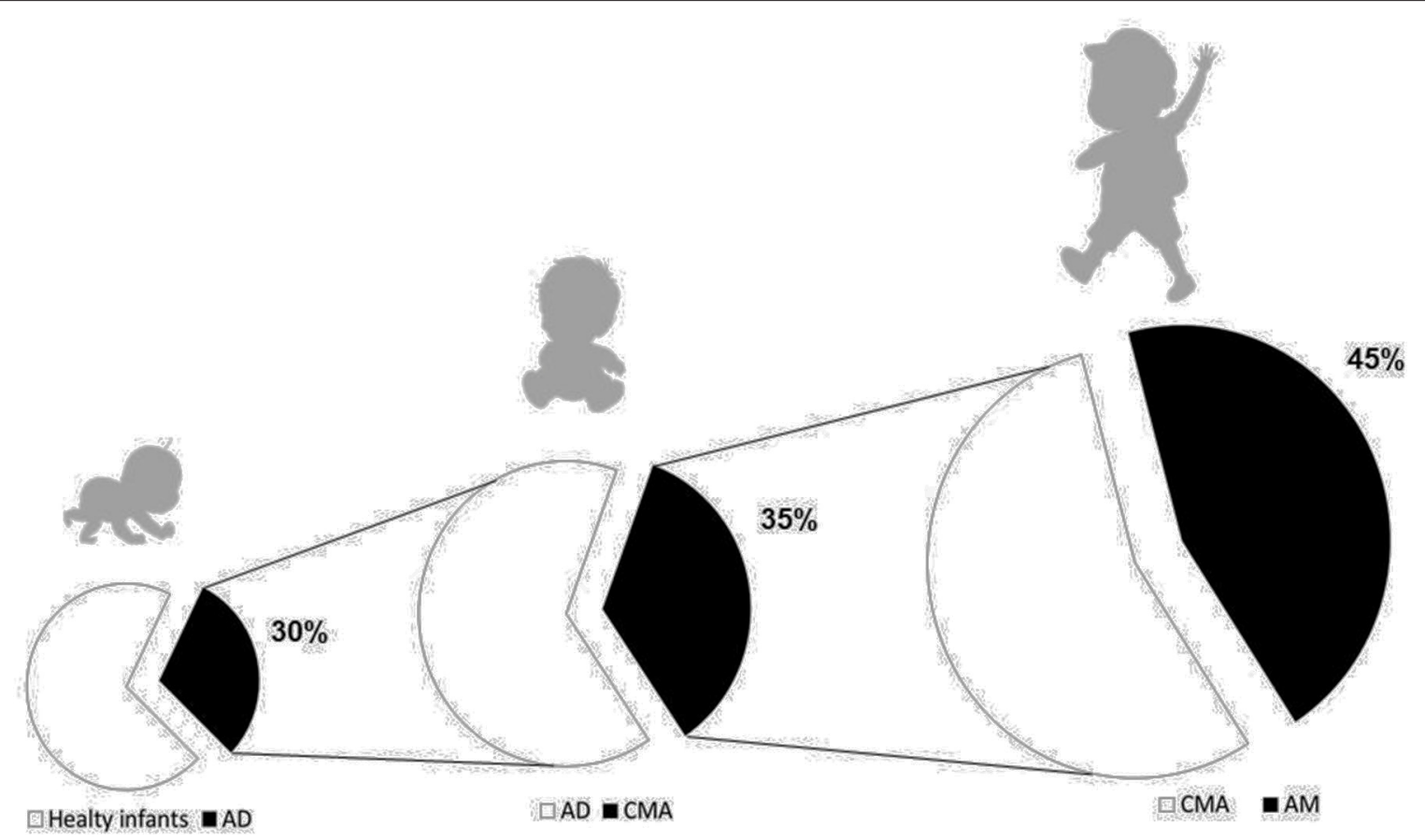

FIGURE 1 | The atopic march in pediatric patients with cow's milk allergy. Atopic dermatitis (AD) is commonly considered the first step of the atopic march (AM), however, $\mathrm{AD}$ and cow's milk allergy (CMA) could co-exist, particularly in those with early onset, severe, and persistent atopic eczema. CMA affects about $1 / 3$ of patients with AD. Data from several clinical studies demonstrate that up to $45 \%$ of children affected by CMA will develop other atopic manifestations later in the life, also after the immune tolerance acquisition to cow's milk proteins. 
TABLE 1 | Main immunomodulatory factors in human milk.

\begin{tabular}{ll}
\hline $\begin{array}{l}\text { Regulation of infant's immune } \\
\text { system through a direct } \\
\text { interaction with immune cells }\end{array}$ & $\begin{array}{l}\text { Regulation of infant's immune } \\
\text { system through a modulation of } \\
\text { gut microbiome }\end{array}$ \\
\hline Cytokines & Lactoferrin \\
Bacterial DNA & Lisozyme \\
miRNAs & Secretory IgA \\
Short chain fatty acids & Human milk bacteria \\
Human milk oligosaccharides & Human milk oligosaccharides \\
Omega-3 fatty acids &
\end{tabular}

probiotic bacteria (41). HMBs can originate from maternal skin, newborn oral cavity, or mostly from the maternal gut (the "entero-mammary pathway") and are influenced by mode of delivery, with a lower bacteria variety and abundance in cesarean compared to vaginal delivery $(42,43)$. Breast milk is considered the second source of microbes to infant GM, and it has been estimated that breastfed infants could receive from human milk microbiota up to $8 \times 10^{5}$ bacteria daily (44). Considering the pivotal role of GM in influencing the infant immune system function against CMA (45), it is possible to hypothesize that HMBs could be an innovative target of intervention. Interestingly, it has been demonstrated that in the milk of allergic mothers the bifidobacteria counts were significantly lower than in the milk of non-allergic mothers (46).

Regarding breast milk non-microbial components, human milk oligosaccharides (HMOs) are a group of non-digestible carbohydrates that are able to regulate the immune system function in a direct or indirect way. The HMO composition in breast milk is influenced by environmental (such as maternal diet) and genetic factors, and a possible role in FA has been suggested (47). Recent studies reported an association between different genetically induced HMO composition and the development of CMA and FA $(47,48)$. Interestingly, one recent study highlighted the ability of specific HMOs, pulled from human milk, to induce the maturation of human monocytederived dendritic cells (DC) (moDC). The derived HMO moDC are able to promote $\mathrm{T}$ reg induction from native $\mathrm{CD} 4^{+} \mathrm{T}$ cells, with a final tolerogenic effect on the infant's immune system (49); but the best characterized HMO properties are related to the prebiotic modulation of early microbial gut colonization with bifidobacteria and lactobacilli, which are involved in the production of tolerogenic metabolites short-chain fatty acids (SCFA), in particular, butyrate (41, 50-54). Supporting this view, it has been reported that the GM of allergic infants lacks genes encoding key enzymes for HMO metabolization with the consequent impairment of butyrate production (55).

Butyrate may prevent allergy diseases though different ways, involving a regulation of the epithelial barrier (at skin, gut, and respiratory tract level), a direct effect on Th1/Th2 cytokine expression, and the activation of regulatory $\mathrm{T}$ cells (Tregs) (56-60). Many effects are mediated by the epigenetic modulation of gene expression, suggesting the possibility of a long-lasting regulatory effect on immune tolerance network (6).
TABLE 2 | Available data on butyrate concentrations in human milk.

\begin{tabular}{|c|c|c|c|c|c|}
\hline References & $\begin{array}{l}\mathrm{N}^{\circ} \\
\text { samples }\end{array}$ & $\begin{array}{c}\mathrm{N}^{\circ} \\
\text { mothers }\end{array}$ & $\begin{array}{l}\text { Min value } \\
\text { (mM) }\end{array}$ & $\begin{array}{c}\text { Max value } \\
(\mathrm{mM})\end{array}$ & Methods \\
\hline $\begin{array}{l}\text { Maria et al. } \\
(68)\end{array}$ & 150 & 30 & 0.1 & 0.23 & $\begin{array}{l}\text { GC-MS utilizing a } \\
\text { lipase assisted } \\
\text { sample preparation } \\
\text { (deuterated butyric } \\
\text { acid (BA-D7) as an } \\
\text { internal standard) }\end{array}$ \\
\hline $\begin{array}{l}\text { Schwab } \\
\text { et al. (70) }\end{array}$ & 19 & 19 & 1.36 & 5.7 & $\begin{array}{l}\text { HPLC-RI with } \\
\text { external standard }\end{array}$ \\
\hline $\begin{array}{l}\text { Prentice } \\
\text { et al. (69) }\end{array}$ & 102 & 102 & 0.0 & 0.4 & H-NMR and GC-MS \\
\hline $\begin{array}{l}\text { Dai et al. } \\
(67)\end{array}$ & 180 & 60 & 0.29 & 0.48 & $\begin{array}{c}\text { Methyl esterification } \\
\text { of SCFAs and GC } \\
\text { analysis }\end{array}$ \\
\hline
\end{tabular}

GC-MS, gas chromatography-mass spectrometry; HPLC-Rl, high performance liquid chromatography with refractive index detection; H-NMR, nuclear magnetic resonance spectroscopy; SCFAs, short chain fatty acids.

The origin of butyrate in breast milk is still largely undefined. The mammalian gland is able to regulate the concentration of several macro- and micronutrients in human milk. Thus, it is possible to hypothesize that some mechanisms of regulation could modulate the butyrate content in human milk. However, recent evidence supports the hypothesis that, at least in part, human milk butyrate could be produced by the HMBs. The hypothesis of a pivotal contribution by mammalian gland/breast milk microbiota in butyrate production is supported by recent observations demonstrating the presence of potential butyrateproducer bugs (54, 61-65).

An example of a potential pathway in butyrate production in breast milk could be derived by HMO metabolization by selected bacteria, as recently demonstrated by others $(62,66)$.

Of note, increasing observations demonstrate the presence of significant butyrate concentrations in breast milk, ranging from 0.01 to $>5.0 \mathrm{mM}(67-70)$ (Table 2).

In line with these data, our preliminary observation from 109 healthy mothers show a median butyrate concentration in mature human milk of $0.75 \mathrm{mM}$ (range $0.16-1.97 \mathrm{mM}$ ) (58). Interestingly, several preclinical data show that this butyrate concentration is able to modulate several components of immune tolerance network mainly through epigenetic mechanisms $(6,56-60)$.

Altogether, these data strongly suggest the potential pivotal role of a modulation of breast milk composition for innovate preventive strategies against CMA and against the occurrence of AM in CMA children.

\section{THE POTENTIAL OF FORMULA CHOICE}

The first evidence on the possible role of infant formulas in preventing AM in CMA infants was provided about 10 years ago. In a prospective cohort study of 119 children with IgE-mediated CMA, a multivariate analysis of risk factors for the occurrence 
TABLE 3 | The studies exploring the potential of formula choice in preventing atopic march in pediatric patients affected by cow's milk allergy.

\begin{tabular}{|c|c|c|c|c|c|c|}
\hline References & $\begin{array}{l}\text { Study } \\
\text { design/population }\end{array}$ & Age & Sample size & Intervention/duration & Outcomes & Results \\
\hline $\begin{array}{l}\text { Berni Canani } \\
\text { et al. (5) }\end{array}$ & $\begin{array}{l}\text { Parallel-arm } \\
\text { RCT/lgE-mediated } \\
\text { CMA }\end{array}$ & $1-12$ months & $\begin{array}{l}N=220 \\
I=110 \\
C=110\end{array}$ & $\begin{array}{l}\mathrm{I}=\mathrm{EHCF}+\mathrm{LGG} \\
\mathrm{C}=\mathrm{EHCF} ; \text { for } 36 \text { months }\end{array}$ & $\begin{array}{l}\text { The occurrence of any atopic } \\
\text { manifestation (eczema, } \\
\text { urticaria, asthma, } \\
\text { oculo-rhinitis) during the } 36 \\
\text { months of the study. }\end{array}$ & $\begin{array}{l}\text { The ARD of any atopic manifestation for } \\
\text { EHCF+LGG vs. EHCF was: } \\
\text { (1) }-0.23 \text { [ } 95 \% \mathrm{Cl}-0.36 \text { to }-0.10, p<0.001] \\
\text { at CCA; } \\
\text { (2) }-0.22 \text { [95\% Cl }-0.35 \text { to }-0.09, p<0.001] \\
\text { at SA-EQS; } \\
\text { (3) }-0.33 \text { [ } 95 \% \mathrm{Cl}-0.45 \text { to }-0.21, p<0.001] \\
\text { at SA-BCS; } \\
\text { (4) }-0.08 \text { [ } 95 \% \mathrm{Cl}-0.21 \text { to } 0.04, p=0.5 \text { ] at } \\
\text { SA-WCS. } \\
\text { The SA-EQS estimate was very similar to the } \\
\text { CCA estimate. On absolute grounds, the } \\
\text { SA-BCS was } 10 \% \text { higher and the SA-WCS } \\
\text { was } 15 \% \text { lower than the CCA estimate. } \\
\text { Even under the worst case scenario, a } \\
\text { difference in favor of EHCF+LGG was still } \\
\text { present ( } 8 \% \text { ). Using the CCA estimate of the } \\
\text { ARD, the NNT was } 4 \text { (95\% Cl } 3 \text { to 10). }\end{array}$ \\
\hline $\begin{array}{l}\text { Sánchez- } \\
\text { Valverde et al. } \\
\text { (71) }\end{array}$ & $\begin{array}{l}\text { Observational cohort } \\
\text { study/ } \\
\text { IgE-mediated CMA }\end{array}$ & $4 \pm 2.63$ months & $N=119$ & $\begin{array}{l}\text { More extensively hydrolyzed high } \\
\text { grade hydrolysates (+EH/HGH), } \\
\text { which are those in which }>95 \% \text { of } \\
\text { peptides are of }<1,000 \mathrm{kDa} \text {, and } \\
\text { less extensively hydrolyzed } \\
\text { hydrolysates and soya milk } \\
\text { formulas. }\end{array}$ & $\begin{array}{l}\text { To evaluate factors that could } \\
\text { predict development of atopic } \\
\text { march in children with } \\
\text { IgE-mediated CMA }\end{array}$ & $\begin{array}{l}\text { Multivariate analysis of risk factor, for the } \\
\text { occurrence of AM revealed that EHCF use } \\
\text { represented a protective factor for other allergic } \\
\text { diseases compared to other hypoallergenic } \\
\text { formulas or soy-based formula (OR 0.76; } 95 \% \\
\text { Cl: } 0.149-0.945, p=0.038 \text { ). }\end{array}$ \\
\hline
\end{tabular}

\begin{tabular}{|c|c|c|c|c|c|c|}
\hline Gil et al. (72) & $\begin{array}{l}\text { Retrospective } \\
\text { observational cohort } \\
\text { study/ } \\
\text { only lgE-mediated } \\
\text { CMA }\end{array}$ & $\begin{array}{l}\text { Mean age at diagnosis } \\
5.07 \pm 2.67 \text { months } \\
\text { Mean age at the end of } \\
\text { follow up } 14.41 \pm \\
5.42 \text { years }\end{array}$ & $N=211$ & $\begin{array}{l}\text { Five groups, based on formula } \\
\text { composition: vegetable-based } \\
\text { formulas (rice or soy), high grade } \\
\text { EHF in which }>95 \% \text { peptides were } \\
1,000 \mathrm{kDa} \text {, high-grade EHF + LGG, } \\
\text { low-grade EHF in which higher } \\
\text { proportion of peptides }>1,000 \\
\mathrm{kDa} \text {, or amino acid-based formulas. }\end{array}$ & $\begin{array}{l}\text { To evaluate if a new scoring } \\
\text { system could determine the } \\
\text { risk of developing allergic } \\
\text { march }\end{array}$ & $\begin{array}{l}\text { The risk of AM occurrence decreased in those } \\
\text { treated with high grade EHF (OR 0.42; } 95 \% \mathrm{Cl} \\
0.20-0.87, p=0.02 \text { ), and these results were } \\
\text { stronger in patients treated with high-grade } \\
\text { EHF + LGG (OR 0.30; } 95 \% \mathrm{Cl} 0.09-0.98, p= \\
0.048 \text { ). }\end{array}$ \\
\hline $\begin{array}{l}\text { Guest and } \\
\text { Fuller (73) }\end{array}$ & $\begin{array}{l}\text { Retrospective cohort } \\
\text { study/ } \\
\text { lgE- and non } \\
\text { lgE-mediated CMA }\end{array}$ & $\begin{array}{l}\text { Mean age } \\
I=4.2 \pm 2.7 \text { months } \\
C=5.4 \pm 2.9 \text { months }\end{array}$ & $\begin{array}{l}N=940 \\
I=470 \\
C=470\end{array}$ & $\begin{array}{l}\mathrm{I}=\mathrm{EHCF}+\mathrm{LGG} \\
\mathrm{C}=\mathrm{EHWF}\end{array}$ & $\begin{array}{l}\text { The occurrence of any allergic } \\
\text { manifestations over a period } \\
\text { of } 24 \text { months from the start of } \\
\text { formula }\end{array}$ & $\begin{array}{l}\text { Binary logistic regression analysis showed that } \\
\text { infants fed with EHWF had a significant higher } \\
\text { relative risk at } 24 \text { months of atopic dermatitis } \\
\text { (OR: } 3.438 ; 95 \% \text { Cl: } 1.975-5.985 ; p<0.001 \text { ) } \\
\text { and asthma (OR: } 2.651 ; 95 \% \text { Cl: } 1.242-5.660 \text {; } \\
p<0.02 \text { ) compared with those fed with } \\
\text { EHCF+LGG. }\end{array}$ \\
\hline
\end{tabular}

RCT, randomized controlled trial; N, total number of subjects; I, intervention; C, control; EHF, extensively hydrolyzed formula; EHCF, extensively hydrolyzed casein formula; LGG, Lactobacillus rhamnosus GG; EHWF, extensively hydrolyzed whey formula; $\mathrm{eHF}$, extensively hydrolyzed formula; IgE, immunoglobulin E; CMA, cow's milk allergy; AM, atopic march; ARD, absolute risk difference; CCA, complete case analysis; SA-EQS, sensitivity analysis - equal worst outcome scenario; SA-BCS, sensitivity analysis - best case scenario; SA-WCS, sensitivity analysis-worst case scenario; NNT, Number needed to treat; $95 \%$ Cl, 95\% confidence interval; OR, odds ratio. 
of AM revealed that the use of an extensively hydrolyzed caseinbased formula (EHCF) represented a protective factor for other allergic diseases, compared to other hypoallergenic formulas or soy-based formulas (OR 0.76; 95\% CI: 0.149-0.945, $p=$ 0.038) (71).

To our knowledge, to date, only one randomized controlled trial was performed to test the potential of a formula-based dietary intervention on AM prevention in CMA pediatric patients (5). In this prospective trial, a total of 220 infants with IgE-mediated CMA (67\% males, median age 5.0 months) were randomized into two dietary groups: 110 subjects were placed on EHCF-based diet, and 110 children were placed on EHCF + probiotic Lactobacillus rhamnosus GG (LGG)-based diet. Patients were followed up for 36 months. In the complete case analysis (CCA), the absolute risk difference (ARD) for the occurrence of at least one atopic manifestation over 36 months was -0.23 (95\% CI -0.36 to $-0.10, p<0.001)$. Even under the worst-case scenario, a difference in favor of EHCF+LGG was still detected. Using the CCA estimate of the ARD, the number needed to treat was 4 (95\% CI 3-10) (5). These findings are consistent with those of recent studies revealing that the first-line approach with EHCF+LGG for CMA infants may slow down the AM, compared to infants treated with other formulas. A retrospective observational study on 211 subjects with CMA was conducted for new score validation for the risk of developing AM, using selected clinical and laboratory data (72). The authors found that the type of substitutive formula for CMA treatment may influence the natural history of these children. They divided the patients into five groups, based on formula composition: vegetable-based formulas (rice or soy), high-grade extensively hydrolyzed formula (EHF) for those in which $>95 \%$ of peptides were $1,000 \mathrm{kDa}$, high-grade
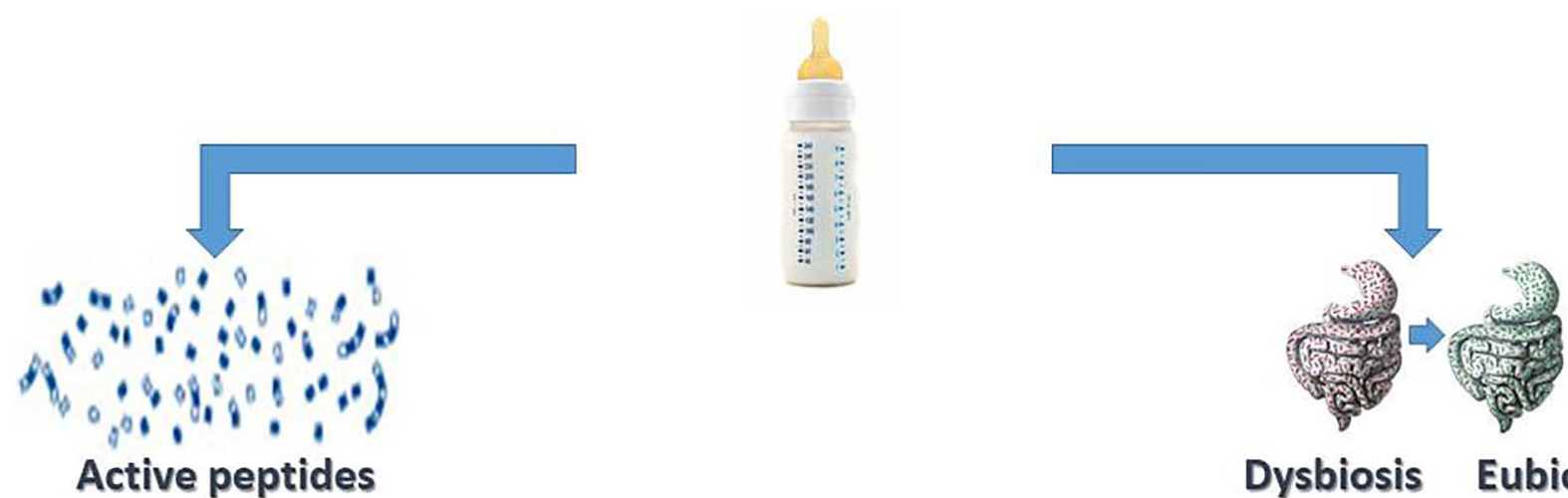

Dysbiosis

Eubiosis

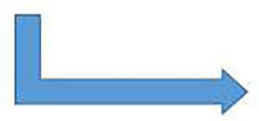

\section{Modulation of immune and non- immune tolerogenic factors}
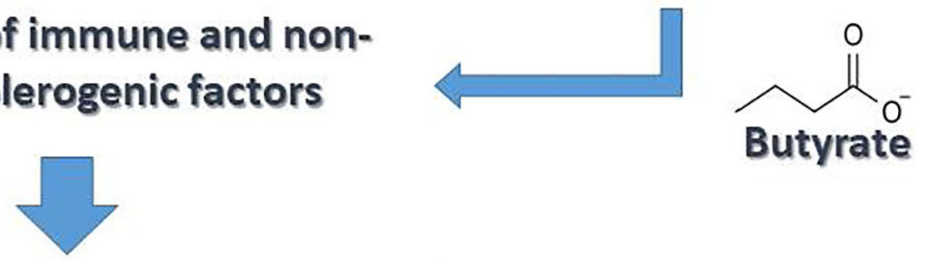

\section{More efficient epigenetic regulation of Th1 and Th2 genes expression}

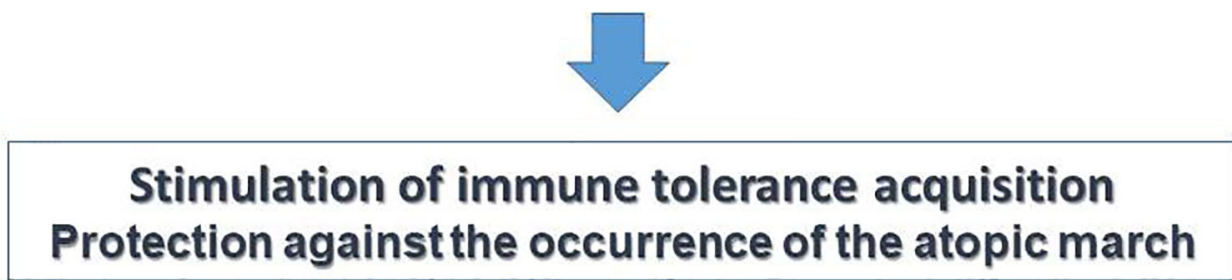

FIGURE 2 | Active diet therapy in pediatric patients with cow's milk allergy. "Active diet therapy" means the possibility to influence the cow's milk allergy (CMA) disease course and to limit the occurrence of other atopic manifestations later in the life. Emerging evidence suggests the importance of formula choice for the management of CMA pediatric patients. It has been demonstrated that the use of extensively hydrolyzed casein formula (EHCF) containing the probiotic $L$. rhamnosus GG (LGG) could exert a modulation of immune tolerance network mediated by the activity of selected casein hydrolysis-derived peptides and by activity of LGG on gut microbiota structure and function leading to an increased production of the short chain fatty acid butyrate. Several non-immune (gut barrier integrity) and immune (cytokines, immune cells) tolerogenic factors are involved in such modulatory action. Many effects are mediated by epigenetic mechanisms. Altogether these mechanisms are able to stimulate a faster acquisition of immune tolerance to cow's milk peptides and to limit the occurrence of atopic march. 
EHF plus LGG (EHF+LGG), low-grade EHF for those with a higher proportion of peptides $(>1,000 \mathrm{kDa})$, or amino acidbased formulas. Authors found that the risk of AM occurrence decreased in those treated with high-grade EHF (OR 0.42; 95\% CI $0.20-0.87, p=0.02$ ), and these results were stronger in patients treated with high-grade EHF+LGG (OR 0.30; 95\% CI $0.09-0.98, p=0.048$ ). The authors concluded that the first-line approach with EHF may be beneficial to prevent the occurrence of AM, and LGG implementation strengthened this trend. They supposed that the hypoallergenic composition of this high-grade EHF and the GM may have helped to positively influence the immune tolerance network, decreasing the risk of developing AM (72). Similarly, in a recent retrospective cohort study of 940 infants with CMA, a binary logistic regression analysis showed that infants fed with extensively hydrolyzed whey formula (EHWF) had a significantly higher relative risk at 24 months of $\mathrm{AD}$ (OR: 3.438; 95\% CI: $1.975-$ 5.985; $p<0.001$ ) and asthma (OR: $2.651 ; 95 \%$ CI: 1.242-5.660; $p<0.02$ ) compared with those fed with EHCF+LGG. The authors concluded that the first-line therapeutic approach for newly diagnosed CMA children with EHCF+LGG, reducing the development of other allergic diseases later in life, may slow down the AM (73). Current guidelines provided by scientific societies (EAACI, DRACMA, NICE, ESPGHAN, NIAID, BSACI) strongly suggest avoiding unmodified animal milk proteins for CMA dietary treatment. In addition, there is no evidence supporting the potential role of such mammalian milks in preventing AM in FA patients (74). All available studies focused on the potential role of formulas in preventing AM are summarized in Table 3.

\section{POTENTIAL MECHANISMS OF ACTION OF INFANT FORMULAS}

It has been suggested that selected milk protein hydrolysates used for CMA management may be able to not only avoid allergic symptoms in CMA infants due to the breakdown of $\operatorname{IgE}$ antigens but also play a role in immune system modulation, inducing tolerance and preventing allergic sensitization (7579). These peptides are able to interact with TLR2 and TLR4, modulating cytokine release by epithelial and immune cells (80). It has also been demonstrated that specific peptides from casein hydrolysates, driving $\mathrm{T}$ cell switching from Th2 to Th1 or to Tregs subtype, could exert a protective effect for FA $(77,81)$. Animal studies have demonstrated that these peptides can suppress Th2 response through an IL-10 up regulation and IL-2 downregulation (75). Moreover, the production of the tolerogenic cytokine IL-10 was higher in Jurkat T cells that underwent a casein hydrolysate stimulus (79). Preliminary data by our group suggest that formula choice is able to induce immune system modulation through epigenetic mechanisms in CMA infants $(17,82,83)$; specifically, evidence suggests that EHCF+LGG is able to modulate GM, raising the abundance of selected genera (Roseburia, Coprococcus, and Blautia) with increased production of butyrate (16). A significant difference in DNA methylation of Th2 and Th1 cytokine (IL-4, IL-5, IL-10, and IFN- $\gamma$ ) genes and of FoxP3, the transcription factor that modulates the fate of Tregs, was observed in infants treated with EHCF+LGG who develop immune tolerance compared to children who received other formulas $(82,83)$. A DNA methylation status of all allergy-related genes in infants treated with EHCF+LGG

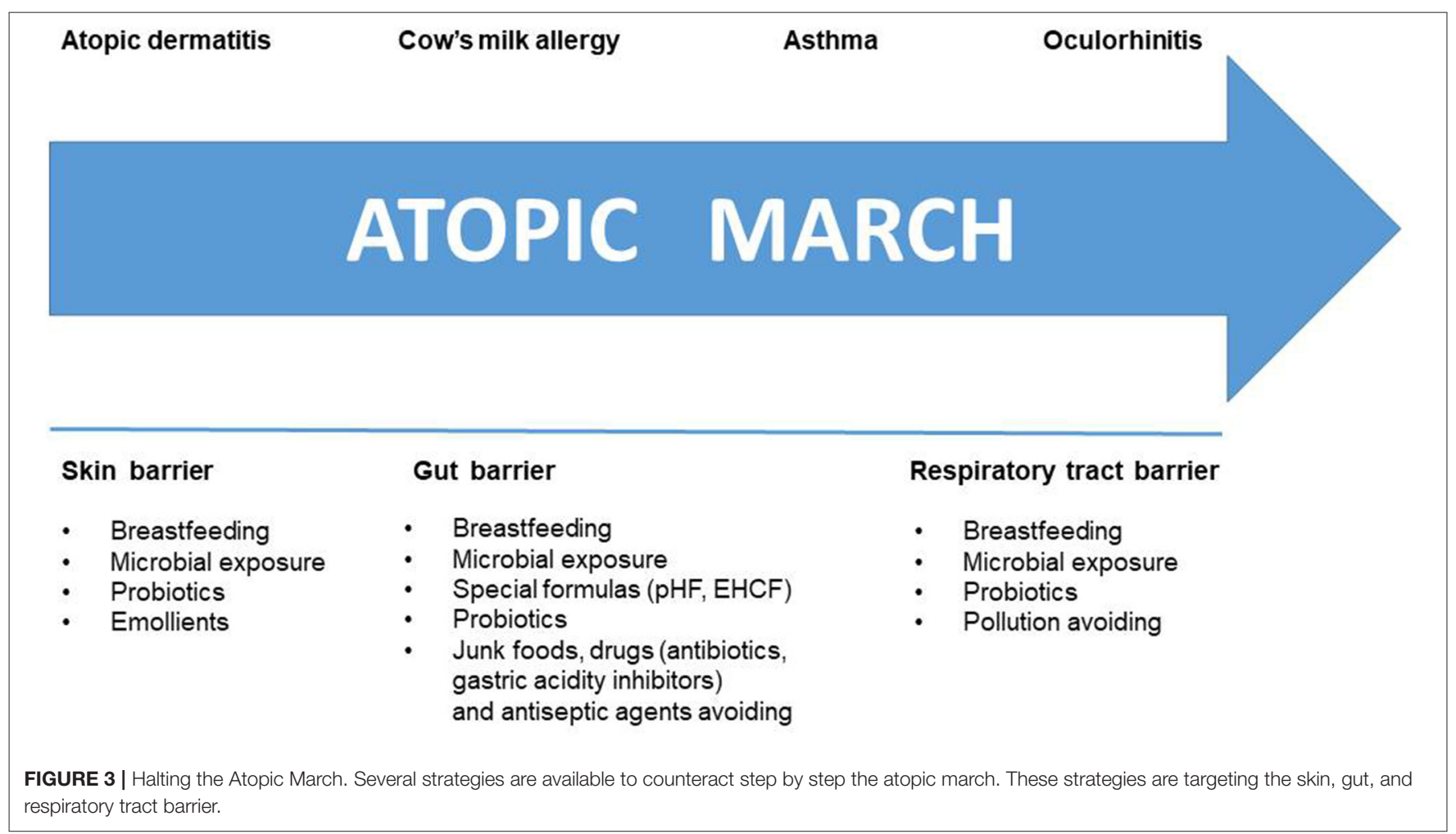


was closer to that observed in healthy children. Analyzing the potential factors able to modulate DNA methylation status in tolerant children, the authors found that the variable that greatly influenced the DNA methylation status was EHCF+LGG formula use $(82,83)$. A longitudinal study, the EPICMA trial, compared the DNA methylation of FoxP3, Th1/Th2 cytokine genes, and allergy-related microRNAs (miRNAs) profile in IgE-mediated CMA infants taking EHCF+LGG compared to soy formula. This study demonstrated that treatment with EHCF+LGG is characterized by a more pronounced effect on FoxP3 demethylation compared to soy formula and by a higher methylation status of IL-4 and IL-5 and a lower methylation status of IL-10 and IFN- $\gamma$ (17). Moreover, children treated with EHCF+LGG showed a selected miRNA expression toward a Th1-oriented response, leading to the activation of immune tolerance mechanisms (17). However, the impact of diet on epigenetic mechanisms may not only be direct but also mediated by the GM (84). So, the Diet-GM-Epigenetic axis creates a coherent picture that may be useful for developing potential strategies against AM in CMA children (Figure 2). Altogether, these data highlight the relevance of "immunenutrition management" able to reduce disease duration and to protect against the occurrence of other atopic manifestations the CMA children.

\section{CONCLUSIONS}

During the last years, much has changed about AM knowledge. The actual strategies to halt the AM are depicted in Figure 3.

\section{REFERENCES}

1. Flom JD, Sicherer SH. Epidemiology of cow's milk. Allergy Nutr. (2019) 11:1051 doi: 10.3390/nu11051051

2. Berni Canani R, Nocerino R, Terrin G, Di Costanzo M, Cosenza L, Troncone R. Food allergy diagnostic practice in Italian children. J Allergy Clin Immunol. (2012) 129:1423-4. doi: 10.1016/j.jaci.2012.02.044

3. Berni Canani R, Nocerino R, Terrin G, Coruzzo A, Cosenza L, Leone L, et al. Effect of lactobacillus GG on tolerance acquisition in infants with cow's milk allergy: a randomized trial. J Allergy Clin Immunol. (2012) 129:580-2, 582.e1-5. doi: 10.1016/j.jaci.2011.10.004

4. Nocerino R, Leone L, Cosenza L, Berni Canani R. Increasing rate of hospitalizations for food-induced anaphylaxis in Italian children: an analysis of the Italian ministry of health database. J Allergy Clin Immunol. (2015) 135:833-5.e3. doi: 10.1016/j.jaci.2014.12.1912

5. Berni Canani R, Di Costanzo M, Bedogni G, Amoroso A, Cosenza L, Di Scala C, et al. Extensively hydrolyzed casein formula containing Lactobacillus rhamnosus GG reduces the occurrence of other allergic manifestations in children with cow's milk allergy: 3-year randomized controlled trial. J Allergy Clin Immunol. (2017) 139:1906-13.e4. doi: 10.1016/j.jaci.2016.10.050

6. Berni Canani R, Paparo L, Nocerino R, Di Scala C, Della Gatta G, Maddalena $\mathrm{Y}$, et al. Gut microbiome as target for innovative strategies against food allergy. Front Immunol. (2019) 10:191. doi: 10.3389/fimmu.2019. 00191

7. Bilaver LA, Chadha AS, Doshi P, O'Dwyer L, Gupta RS. Economic burden of food allergy: a systematic review. Ann Allergy Asthma Immunol. (2019) 122:373-80.e1. doi: 10.1016/j.anai.2019.01.014

8. Pensabene L, Salvatore S, D'Auria E, Parisi F, Concolino D, Borrelli $\mathrm{O}$, et al. Cow's milk protein allergy in infancy: a risk factor for
Despite the lack of cure, novelties about CMA dietary management are moving from "passive" elimination diet to an "active diet-therapy" able to reduce disease duration and to protect against the occurrence of AM. The latter strategy is supported by better knowledge on the role of diet, breastfeeding, gut microbiome, and tolerogenic mechanisms. Thus, an active diet-therapy able to modulate the GM composition, restoring microbial equilibrium and optimal butyrate production, is a positive example of the potential of such strategy. The best nutritional choice for CMA infants is breastfeeding, but recent evidence suggests that breast milk composition could be influenced by environmental factors including maternal diet that could represent relevant target of intervention for preventive strategy against $\mathrm{AM}$ in CMA infants. If breastfeeding is not possible, evidence suggests that casein hydrolysate-based infant formula with the adjunction of the probiotic LGG could be able to stimulate immune tolerance acquisition and to reduce the incidence of $\mathrm{AM}$ in children with CMA.

\section{AUTHOR CONTRIBUTIONS}

$\mathrm{RB}$ designed and structured the review, wrote, and read the manuscript. LC and RN analyzed literature, wrote, and read the manuscript. LP and CD analyzed literature and read the manuscript. All authors listed have made a substantial, direct, and intellectual contribution to the work, and approved it for publication. functional gastrointestinal disorders in children? Nutrients. 10:1716. doi: 10.3390/nu10111716

9. Levy Y, Segal N, Garty B, Danon YL. Lessons from the clinical course of IgE-mediated cow milk allergy in Israel. Pediatr Allergy Immunol. (2007) 18:589-93. doi: 10.1111/j.1399-3038.2007.00562.x

10. Skripak JM, Matsui EC, Mudd K, Wood RA. The natural history of IgEmediated cow's milk allergy. J Allergy Clin Immunol. (2007) 120:11727. doi: $10.1016 /$ j.jaci.2007.08.023

11. Savage J, Sicherer S, Wood R. The natural history of food allergy. J Allergy Clin Immunol Pract. (2016) 4:196-203. doi: 10.1016/j.jaip.2015.11.024

12. Berni Canani R, Gilbert JA, Nagler CR. The role of the commensal microbiota in the regulation of tolerance to dietary allergens. Curr Opin Allergy Clin Immunol. (2015) 15:243-9. doi: 10.1097/ACI.0000000000000157

13. Porsbjerg C, von Linstow ML, Ulrik CS, Nepper-Christensen S, Backer V. Risk factors for onset of asthma: a 12-year prospective follow-up study. Chest. (2006) 129:309-16. doi: 10.1378/chest.129.2.309

14. Dharma C, Lefebvre DL, Tran MM, Lou WYW, Subbarao P, Becker AB, et al. Patterns of allergic sensitization and atopic dermatitis from 1 to 3 years: effects on allergic diseases. Clin Exp Allergy. (2018) 48:48-59. doi: 10.1111/cea.13063

15. Tran MM, Lefebvre DL, Dharma C, Dai D, Lou WYW, Subbarao P, et al Predicting the atopic march: results from the canadian healthy infant longitudinal development study. J Allergy Clin Immunol. (2018) 141:6017.e8. doi: 10.1016/j.jaci.2017.08.024

16. Berni Canani R, Sangwan N, Stefka AT, Nocerino R, Paparo L, Aitoro R, et al. Lactobacillus rhamnosus GG supplemented formula expands butyrate producing bacterial strains in food allergic infants. ISME J. (2016) 10:74250. doi: 10.1038/ismej.2015.151

17. Paparo L, Nocerino R, Bruno C, Di Scala C, Cosenza L, Bedogni G, et al. Randomized controlled trial on the influence of dietary intervention on 
epigenetic mechanisms in children with cow's milk allergy: the EPICMA study. Sci Rep. (2019) 9:2828. doi: 10.1038/s41598-019-38738-w

18. Berni Canani R, Nocerino R, Terrin G, Frediani T, Lucarelli S, Cosenza L, et al. Formula selection for management of children with cow's milk allergy influences the rate of acquisition of tolerance: a prospective multicenter study. J Pediatr. (2013) 163:771-7. doi: 10.1016/j.jpeds.2013.03.008

19. Busse WW. The atopic march: fact or folklore? Ann Allergy Asthma Immunol. (2018) 120:116-18. doi: 10.1016/j.anai.2017.10.029

20. Bawany F, Beck LA, Järvinen KM. Halting the march: primary prevention of atopic dermatitis and food allergies. J Allergy Clin Immunol Pract. (2020) 8:860-75. doi: 10.1016/j.jaip.2019.12.005

21. Host A, Halken S. Hypoallergenic formulas-when, to whom and how long: after more than 15 years we know the right indication! Allergy. (2004). 59 (Suppl. 78):45-52. doi: 10.1111/j.1398-9995.2004.00574.x

22. Hays T, Wood RA. A systematic review of the role of hydrolyzed infant formulas in allergy prevention. Arch Pediatr Adolesc Med. (2005) 159:8106. doi: 10.1001/archpedi.159.9.810

23. Koletzko S, Niggemann B, Arato A, Dias JA, Heuschkel R, Husby S, et al. Diagnostic approach and management of cow's-milk protein allergy in infants and children: ESPGHAN GI committee practical guidelines. J Pediatr Gastroenterol Nutr. (2012) 55:221-9. doi: 10.1097/MPG.0b013e31825c9482

24. D'Auria E, Abrahams M, Zuccotti GV, Venter C. Personalized nutrition approach in food allergy: is it prime time yet? Nutrients. (2019) 11:359. doi: 10.3390/nu11020359

25. D’Auria E, Mameli C, Piras C, Cococcioni L, Urbani A, Zuccotti $\mathrm{GV}$, et al. Precision medicine in cow's milk allergy: proteomics perspectives from allergens to patients. J Proteomics. (2018) 188:173-80. doi: 10.1016/j.jprot.2018.01.018

26. D'Auria E, Salvatore S, Pozzi E, Mantegazza C, Sartorio MUA, Pensabene L, et al. Cow's milk allergy: immunomodulation by dietary intervention. Nutrients. (2019) 11:1399. doi: 10.3390/nu11061399

27. Greer FR, Sicherer SH, Burks AW, American Academy of Pediatrics Committee on Nutrition, American Academy of Pediatrics Section on Allergy and Immunology. Effects of early nutritional interventions on the development of atopic disease in infants and children: the role of maternal dietary restriction, breastfeeding, timing of introduction of complementary foods, and hydrolyzed formulas. Pediatrics. (2008) 121:18391. doi: 10.1542/peds.2007-3022

28. Muraro A, Werfel T, Hoffmann-Sommergruber K, Roberts G, Beyer K, Bindslev-Jensen C, et al. EAACI food allergy and anaphylaxis guidelines: diagnosis and management of food allergy. Allergy. (2014) 69:100825. doi: $10.1111 /$ all.12429

29. Liao SL, Lai SH, Yeh KW, Huang YL, Yao TC, Tsai MH, et al. The PATCH (the prediction of allergy in Taiwanese children) cohort study: exclusive breastfeeding is associated with reduced cow's milk sensitization in early childhood. Pediatr Allergy Immunol. (2014) 25:456-61. doi: 10.1111/pai. 12247

30. Kull I, Wickman M, Lilja G, Nordvall SL, Pershagen G. Breast feeding and allergic diseases in infants-a prospective birth cohort study. Arch. Dis. Child. (2002) 87:478-81. doi: 10.1136/adc.87.6.478

31. Sears MR, Greene JM, Willan AR, Taylor DR, Flannery EM, Cowan JO, et al. Long-term relation between breastfeeding and development of atopy and asthma in children and young adults: a longitudinal study. Lancet. (2002) 360:901-7. doi: 10.1016/S0140-6736(02)11025-7

32. Fleischer DM, Spergel JM, Assa'ad AH, Pongracic JA. Primary prevention of allergic disease through nutritional interventions. J Allergy Clin Immunol Pract. (2013) 1:29-36. doi: 10.1016/j.jaip.2012.09.003

33. Saarinen UM, Kajosaari M. Breastfeeding as prophylaxis against atopic disease: prospective follow-up study until 17 years old. Lancet. (1995) 346:1065-9. doi: 10.1016/s0140-6736(95)91742-x

34. Horta B, Bahl R, Martines J, Victoria CG. Evidence of the Long-Term Effects of Breastfeeding: Systematic Reviews and Meta-analysis. Geneva: WHO (2007).

35. van Ginkel CD, van der Meulen GN, Bak E, Flokstra-de Blok BMJ, Kollen BJ, Koppelman GH, et al. Retrospective observational cohort study regarding the effect of breastfeeding on challenge-proven food allergy. Eur J Clin Nutr. (2018) 72:557-63. doi: 10.1038/s41430-018-0117-y
36. Lodge CJ, Tan DJ, Lau MX, Dai X, Tham R, Lowe AJ, et al. Breastfeeding and asthma and allergies: a systematic review and meta-analysis. Acta Paediatr. (2015) 104:38-53. doi: 10.1111/apa.13132

37. Kramer MS, Chalmers B, Hodnett ED, Sevkovskaya Z, Dzikovich I, Shapiro S, et al. Promotion of breastfeeding intervention trial (probit): a randomized trial in the republic of belarus. JAMA. (2001) 285:41320. doi: 10.1001/jama.285.4.413

38. Cox LM, Yamanishi S, Sohn J, Alekseyenko AV, Leung JM, Cho I, et al. Altering the intestinal microbiota during a critical developmental window has lasting metabolic consequences. Cell. (2014) 158:705-21. doi: 10.1016/j.cell.2014.05.052

39. Nolan LS, Parks OB, Good M. A review of the immunomodulating components of maternal breast milk and protection against necrotizing enterocolitis. Nutrients. (2019) 12:14. doi: 10.3390/nu12010014

40. van den Elsen LWJ, Garssen J, Burcelin R, Verhasselt V. Shaping the gut microbiota by breastfeeding: the gateway to allergy prevention? Front Pediatr. (2019) 7:47. doi: 10.3389/fped.2019.0004

41. Lyons KE, Ryan CA, Dempsey EM, Ross RP, Stanton C. Breast milk, a source of beneficial microbes and associated benefits for infant health. Nutrients. (2020) 12:1039. doi: 10.3390/nu12041039

42. Iozzo P, Sanguinetti E. Early dietary patterns and microbiota development: still a way to go from descriptive interactions to health-relevant solutions. Front Nutr. (2018) 5:5. doi: 10.3389/fnut.2018.00005

43. Cabrera-Rubio R, Mira-Pascual L, Mira A, Collado MC. Impact of mode of delivery on the milk microbiota composition of healthy women. J Dev Orig Health Dis. (2016) 7:54-60. doi: 10.1017/S2040174415001397

44. Pannaraj PS, Li F, Cerini C, Bender JM, Yang S, Rollie A, et al. Association between breast milk bacterial communities and establishment and development of the infant gut microbiome. JAMA Pediatr. (2017) 171:64754. doi: 10.1001/jamapediatrics.2017.0378

45. Feehley T, Plunkett CH, Bao R, Choi Hong SM, Culleen E, Belda-Ferre P, et al. Healthy infants harbor intestinal bacteria that protect against food allergy. Nat Med. (2019) 25:448-53. doi: 10.1038/s41591-018-0324-Z

46. Grönlund M, Gueimonde M, Laitinen K, Kociubinskiz G, Grönroosz $\mathrm{T}$, Salminen S, et al. Maternal breast-milk and intestinal bifidobacteria guide the compositional development of the Bifidobacterium microbiota in infants at risk of allergic disease. Clin Exp Allergy. (2007) 37:176472. doi: 10.1111/j.1365-2222.2007.02849.x

47. Miliku K, Robertson B, Sharma AK, Subbarao P, Becker AB, Mandhane PJ, et al. Human milk oligosaccharide profiles and food sensitization among infants in the CHILD study. Allergy. (2018) 73:2070-3. doi: 10.1111/all.13476

48. Seppo AE, Autran CA, Bode L, Järvinen KM. Human milk oligosaccharides and development of cow's milk allergy in infants. J Allergy Clin Immunol. (2017) 139:708-11.e5. doi: 10.1016/j.jaci.2016.08.031

49. Xiao L, van De Worp WR, Stassen R, van Maastrigt C, Kettelarij N, Stahl $\mathrm{B}$, et al. Human milk oligosaccharides promote immune tolerance via direct interactions with human dendritic cells. Eur J Immunol. (2019) 49:100114. doi: 10.1002/eji.201847971

50. Isolauri E. Development of healthy gut microbiota early in life. J Paediatr Child Health. (2012) 48 (Suppl. 3):1-6. doi: 10.1111/j.1440-1754.2012.02489.x

51. Bode L. The functional biology of human milk oligosaccharides. Early Hum Dev. (2015) 91:619-22. doi: 10.1016/j.earlhumdev.2015.09.001

52. Cacho NT, Lawrence RM. Innate immunity and breast milk. Front Immonol. (2017) 8:584. doi: 10.3389/fimmu.2017.00584

53. Lee KH, Song Y, Wu W, Yu K, Zhang G. The gut microbiota, environmental factors, and links to the development of food allergy. ClinMol Allergy. (2020) 18:5. doi: 10.1186/s12948-020-00120-x

54. Walker WA, Iyengar RS. Breast milk, microbiota, and intestinal immune homeostasis. Pediatr Res. (2015) 77:220-8. doi: 10.1038/pr.2014.160

55. Cait A, Cardenas E, Dimitriu P, Amenyogbe N, Dai D, Cait J, et al. Reduced genetic potential for butyrate fermentation in the gut microbiome of infants who develop allergic sensitization. J Allergy Clin Immunol. (2019) 144:163847.e3. doi: 10.1016/j.jaci.2019.06.029

56. Wang J, Wen L, Wang Y Chen F. Therapeutic effect of histone deacetylase, sodium butyrate, on allergic rhinitis in vivo. DNA Cell Biol. (2016) 35:2038. doi: 10.1089/dna.2015.3037 
57. Cait A, Hughes MR, Antignano F, Cait J, Dimitriu PA, Maas KR, et al. Microbiome-driven allergic lung inflammation is ameliorated by short-chain fatty acids. Mucosal Immunol. (2018) 11:785-95. doi: 10.1038/mi.2017.75

58. Berni Canani R, Aitoro R, Paparo L, Amoroso A, Trinchese G, Meli R, et al. Preventive effect of human milk against food allergy: new insights into butyrate activities. J Pediatr Gastroenterol Nutr. (2017) 64 (Suppl. 1):821. doi: 10.1097/01.mpg.0000516381.25680.b4

59. Shi Y, Xu LZ, Peng K, Wu W, Wu R, Liu ZQ, et al. Specific immunotherapy in combination with Clostridium butyricum inhibits allergic inflammation in the mouse intestine. Sci Rep. (2015) 5:17651. doi: 10.1038/srep17651

60. Licciardi PV, Ververis K Karagiannis TC. Histone deacetylase inhibition and dietary short-chain fatty acids. ISRN Allergy. (2011) 2011:869647. doi: 10.5402/2011/869647

61. Moossavi S, Sepehri S, Robertson B, Bode L, Goruk S, Field CJ, et al. Composition and variation of the human milk microbiota are influenced by maternal and early-life factors. Cell Host Microbe. (2019) 25:32435.e4. doi: 10.1016/j.chom.2019.01.011

62. Moossavi S, Atakora F, Miliku K, Sepehri S, Robertson B, Duan $\mathrm{QL}$, et al. Integrated analysis of human milk microbiota with oligosaccharides and fatty acids in the child cohort. Front Nutr. (2019) 6:58. doi: 10.3389/fnut.2019.00058

63. McGuire MK, McGuire MA. Got bacteria? The astounding, yet not-sosurprising, microbiome of human milk. Curr Opin Biotechnol. (2017) 44:638. doi: 10.1016/j.copbio.2016.11.013

64. Rautava S. Early microbial contact, the breast milk microbiome and child health. J Dev Orig Health Dis. (2016) 7:5-14. doi: 10.1017/S2040174415 001233

65. Padilha M, Danneskiold-Samsøe NB, Brejnrod A, Hoffmann C, Cabral VP, Iaucci JM, et al. The human milk microbiota is modulated by maternal diet. Microorganisms. (2019) 7:502. doi: 10.3390/microorganisms7110502

66. Munblit D, Verhasselt V. Allergy prevention by breastfeeding: possible mechanisms and evidence from human cohorts. Curr Opin Allergy Clin Immunol. (2016) 16:427-33. doi: 10.1097/ACI.0000000000000303

67. Dai X, Yuan T, Zhang X, Zhou Q, Bi H, Yu R, et al. Short-chain fatty acid (SCFA) and medium-chain fatty acid (MCFA) concentrations in human milk consumed by infants born at different gestational ages and the variations in concentration during lactation stages. Food Funct. (2020) 11:186980. doi: 10.1039/c9fo02595b

68. Maria S, Shu SP, Cundiff JK, Gray M, Lambers TT, Phillips SC, et al. Longitudinal analysis of butyrate in human milk: a GEHM study of three global cohorts through the first year of lactation. J Pediatr Gastroenterol Nutr. (2018) 66 (Suppl. 2):879. doi: 10.1097/MPG.0000000000002005

69. Prentice PM, Schoemaker MH, Vervoort J, Hettinga K, Lambers TT, van Tol EAF, et al. Human milk short-chain fatty acid composition is associated with adiposity outcomes in infants. J Nutr. (2019) 149:71622. doi: $10.1093 / \mathrm{jn} / \mathrm{nxy} 320$

70. Schwab C, Voney E, Ramirez Garcia A, Vischer M, Lacroix C. Characterization of the cultivable microbiota in fresh and stored mature human breast milk. Front Microbiol. (2019) 10:2666. doi: 10.3389/fmicb.2019.02666

71. Sánchez-Valverde F, Gil F, Martinez D, Fernandez B, Aznal E, Oscoz M, et al. The impact of caesarean delivery and type of feeding on cow's milk allergy in infants and subsequent development of allergic march in childhood. Allergy. (2009) 64:884-9. doi: 10.1111/j.1398-9995.2008.01931.x

72. Gil F, Mendizabal M, Amezqueta A, Aznal E, Durá T, Sánchez-Valverde F. A new score to predict allergic march in patients with IgE-mediated cow milk allergy. Allergy Asthma Proc. (2019) 40:187-92. doi: 10.2500/aap.2019. 40.4208
73. Guest JF, Fuller GW. Effectiveness of using an extensively hydrolyzed casein formula supplemented with Lactobacillus rhamnosus GG compared with an extensively hydrolyzed whey formula in managing cow's milk protein allergic infants. J Comp Eff Res. (2019) 8:1317-26. doi: 10.2217/cer-2019-0088

74. Fox A, Brown T, Walsh J, Venter C, Meyer R, Nowak-Wegrzyn A, et al. An update to the milk allergy in primary care guideline. Clin Transl Allergy. (2019) 9:40. doi: 10.1186/s13601-019-0281-8

75. Kiewiet MBG, Gros M, van Neerven RJJ, Faas MM, de Vos P. Immunomodulating properties of protein hydrolysates for application in cow's milk allergy. Pediatr Allergy Immunol. (2015) 26:206-17. doi: 10.1111/pai.12354

76. Sandré C, Gleizes A, Forestier F, Gorges-Kergot R, Chilmonczyk S, Léonil $\mathrm{J}$, et al. A peptide derived from bovine beta-casein modulates functional properties of bone marrow-derived macrophages from germfree and human flora-associated mice. J Nutr. (2001) 131:2936-42. doi: 10.1093/jn/131.11.2936

77. Nagpal R, Behare P, Rana R, Kumar A, Kumar M, Arora S, et al. Bioactive peptides derived from milk proteins and their health beneficial potentials: an update. Food Funct. (2011) 2:18. doi: 10.1039/c0fo00016g

78. Elsayed S, Eriksen J, Øysaed LK, Idsøe R, Hill DJ. T cell recognition pattern of bovine milk alphaS1-casein and its peptides. Mol Immunol. (2004) 41:122534. doi: 10.1016/j.molimm.2004.05.010

79. Laharta N, O'Callaghana Y, Ahernea SA, O'Sullivan D, FitzGerald RJ, O'Brien NM. Extent of hydrolysis effects on casein hydrolysate bioactivity: evaluation using the human jurkat t cell line. Int Dairy J. (2011) 21:77782. doi: 10.1016/j.idairyj.2011.03.014

80. Ndiaye F, Tri V, Duarte J, Aluko RE, Matar C. Anti-oxidant, antiinflammatory and immunomodulating properties of an enzymatic protein hydrolysate from yellow field pea seeds. Eur J Nutr. (2012) 51:2937. doi: 10.1007/s00394-011-0186-3

81. Wong $\mathrm{K}$, Middleton $\mathrm{N}$, Montgomery $\mathrm{M}$, Dey $\mathrm{M}$, Carr $\mathrm{R}$. Immunostimulation of murine spleen cells by materials associated with bovine milk protein fractions. J Dairy Sci. (1998) 81:182532. doi: 10.3168/jds.S0022-0302(98)75752-2

82. Berni Canani R, Paparo L, Nocerino R, Cosenza L, Pezzella V, Di Costanzo M, et al. Differences in DNA methylation profile of Th1and Th2 cytokine genes are associated with tolerance acquisition in children with IgE-mediated cow's milk allergy. Clin. Epigenet. (2015) 7:38. doi: 10.1186/s13148-015-0070-8

83. Paparo L, Nocerino R, Cosenza L, Aitoro R, D’Argenio V, Del Monaco V, et al. Epigenetic features of FoxP3 in children with cow's milk allergy. Clin Epigenetics. (2016) 8:86. doi: 10.1186/s13148-016-0252-z

84. Salazar N, Valdés-Varela L, González S, Gueimonde M, de los Reyes-Gavilán CG. Nutrition and the gut microbiome in the elderly. Gut Microbes. (2017) 8:82-97. doi: 10.1080/19490976.2016

Conflict of Interest: The Department of Translational Medical Science received research grants from Danone, Kraft Heinz, Humana, Mead Johnson Nutrition, Nestlè, and United Pharmaceutical.

The authors have no other conflict of interests that are directly relevant to the content of this paper, which remains their sole responsibility.

Copyright (C) 2020 Carucci, Nocerino, Paparo, Di Scala and Berni Canani. This is an open-access article distributed under the terms of the Creative Commons Attribution License (CC BY). The use, distribution or reproduction in other forums is permitted, provided the original author(s) and the copyright owner(s) are credited and that the original publication in this journal is cited, in accordance with accepted academic practice. No use, distribution or reproduction is permitted which does not comply with these terms. 